\title{
Are Water Resources Sufficient to Support the Proposed Development in the Northern Province?
}

\author{
Hemanthi Ranasinghe
}

Dept. of Forestry and Environmental Science

University of Sri Jayewardenepura

Nugegoda, Sri Lanka

Corresponding Author:

Tel: + 9471447 8756, Email: hemanthi.ranasinghe@gmail.com

\begin{abstract}
After more than 30 years of armed conflict the Northern Province is on its path of development. Under the massive development programme of the North namely 'Uthuru Wasanthaya' development of infrastructure, resettlement, development of agriculture and other livelihoods are being done at an accelerated rate. One of the major drivers in development is water as it is required for all life activities including consumption and other life activities for living beings, farming, fisheries, industries etc. The quantity and quality of water are equally important. According to the National Water Use Master Plan which is still under preparation, the estimated water demand for the Northern Province for 2025 is $4.6 \mathrm{mcm} /$ day of which $3.3 \mathrm{mcm} /$ day will be required for the urban population. The paper describes the availability and potential of both surface and ground water resources in the districts of the Northern Province i.e. Jaffna, Kilinochchi, Mulativu, Mannar and Vavuniya. It also highlights the issues of water with regard to quality, quantity and unsustainable development. The planned and existing water supply schemes are described with their ability to provide the required water. The paper also brings to the notice the existing strategies already in place (i.e. ISEA) and ones that can be adopted towards making the proposed development sustainable in the context of water.
\end{abstract}

KEYWORDS: Water, Northern Province, Development

\section{Introduction}

\section{Northern Province of Sri Lanka}

The Northern Province is one of the nine provinces of Sri Lanka. It is located in the north of Sri Lanka and is just 22 miles $(35 \mathrm{~km})$ from India. It has a land area of 
8,884 square kilometers. The Province is surrounded by the Gulf of Mannar and Palk Bay to the west, Palk Strait to the north west, the Bay of Bengal to the north and east and the Eastern, North Central and North Western Provinces to the south. It covers about $14 \%$ of total land mass of Sri Lanka. Northern Province consists of five districts namely, Jaffna, Kilinochchi, Mullaitivu, Vavuniya and Mannar. Around $40 \%$ of Sri Lanka's coastal area is within the Province. Much of the Northern Province was under the control of rebel Liberation Tigers of Tamil Eelam for many years during the civil war. The entire Province was recaptured by the Sri Lankan military in 2009.

\section{Water Resources in the Province}

The Province is divided into two distinct geographic areas: Jaffna Peninsula and the Vanni. Jaffna Peninsula is irrigated by underground aquifers fed by wells whereas the Vanni has irrigation tanks fed by rivers. Major rivers include: Akkarayan Aru, Aruvi Aru, Kanakarayan Aru, Kodalikkallu Aru, Mandekal Aru, Nay Aru, Netheli Aru, Pali Aru, Pallavarayankaddu Aru, Parangi Aru, Per Aru, Piramenthal Aru, Theravil Aru. Most of these rivers are not perennial.

The Province has a number of lagoons, the largest being Jaffna Lagoon, Nanthi Kadal, Chundikkulam Lagoon, Vadamarachchi Lagoon, Uppu Aru Lagoon, Kokkilai lagoon, Nai Aru Lagoon and Chalai Lagoon. Ground water surveys done prior to the conflict indicate that intensive agriculture, especially paddy, cannot be supported without adequate replenishment of surface water storage. Water scarcity is a main constraint in many parts of the province, even for drinking and domestic use plus quality of drinking water available in the northern districts (Northern Provincial Council, 2011). The drinking water coverage for the districts Kilinochchi, Vavuniya, Mulativu is very little as shown below.

\begin{tabular}{lc} 
District & Percentage \\
\hline Jaffna & $15 \%$ \\
Kilinochchi & $2 \%$ \\
Mannar & $20 \%$ \\
Vavuniya & $4 \%$ \\
Mulathivu & $3 \%$ \\
\hline
\end{tabular}

(Source: WRB, 2009)

\section{Socio Economic Condition in the Province}

The Province has an estimated population of $1.187 \mathrm{mn}$ in 2009 . It is still predominantly an agricultural region having crop, live stock \& fisheries as pivot sub sectors. The diversification process which gained momentum in the country after 1970 and the declining trends of agricultural contribution to the GDP is not properly 
reflected in the current statistics of the Northern Province. However, its contributions to the GDP by agriculture and fisheries sectors have declined during the conflict period. Contribution of these sectors has been gradually increasing form the year 2010 and this trend needs to be strengthened.

Prior to the conflict, i.e. in 1980s, the contribution to GDP by the Northern Province was around 7\%. Later this suffered a negative trend and in 2009 it is shown as $3.3 \%$ and there is a slight improvement when compared to 3.2\% recorded in 2008. This shows that there are potentials in the Northern Province and that should be tapped. The structure of the provincial economy has not changed over the period. However, Agriculture, including Fisheries and Animal husbandry which is the mainstay of the economy has shown positive growth after 2002.

The growth rate has now reached a negative phenomena resulting in a per capita Income of Rs.134, 000 equivalent to US\$ 1166 per year as opposed to the national average of Rs.235, 945 equivalent to US\$ 2053 in 2009.The province struggled to sustain its literacy rate at $92.5 \%$ while suffering from severe disruption in the educational system resulting in high rate of drop out and non attendance in the country. Resettlement activities are taking place in the all 5 Districts in the Northern Province of Jaffna, Kilinochchi, Mullaitivu, Mannar and Vavuniya. Total numbers of displaced people are estimated at 350,028 and out of this displaced people in the North 329,973 Nos. have been re-settled up to November 2010.

However under the "Vadakkin Vasantham Programme" (Uthuru Wasanthaya) the Government has started rehabilitating the buildings, reactivating the livelihood, reconstructing the damage to productivity infrastructure and has taken necessary action for the maintenance of assets, and to increase the level of service delivery and production. A total investment of Rs. 295 Billion had been allocated for the planned investment programme for the period 2010-2012 and the programme's medium term development strategy included the following:

- Restoration of socio economic and personal stability and safety.

- Reconciliation across ethnic borders.

- Revitalization of livelihoods and productive sector.

- Infrastructures - Roads - Electricity - Ports - Transport - Housing -

- Communication, Water supply and sanitation.

- Rural economy through technological transformation.

- Pro poor growth and reduction of disparities.

- Exploitation of marine resources and mineral resources.

- Information Technology and vocational education.

- Institutional reforms and performance improvement.

- Industrial estates, economic centers and private investment. 
One of the major drivers in development is water as this is a limitation in many areas of the Province in terms of quantity as well as quality. According to the National Water Use Master Plan, the estimated water demand for the Northern Province for 2025 is $4.6 \mathrm{mcm} /$ day of which $3.3 \mathrm{mcm} /$ day will be required for the urban population (WRB, 2009).

The objective of this paper is to review the status with regards to the water demand and the supply situation in the districts of the Northern Province using existing data and emulate the potentials and issues in the water balance using secondary dat.

\section{Status and Constraints Related to Water Resources in the Northern Province}

Figures 1 to 3 shows the results of the situation with regard to the status of water resources and potential for extraction in the different districts of the Northern Province done by Integrated Strategic Environmental Assessment (ISEA) conducted by the Central Environmental Authority and United Nations Development Project (UNDP) in collaboration with the stakeholders in the Northern Province.

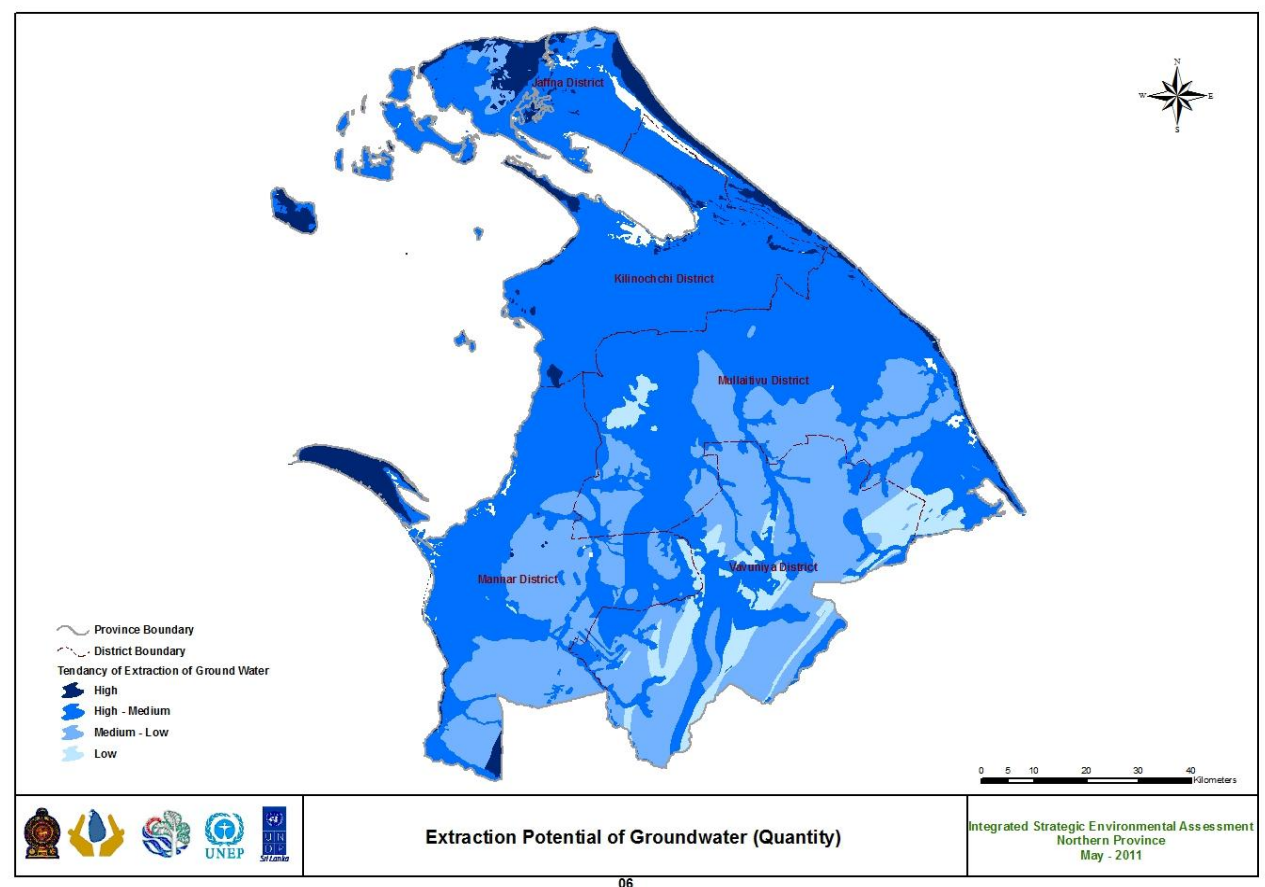

Figure 1: Extraction potential of groundwater in the Northern Province 


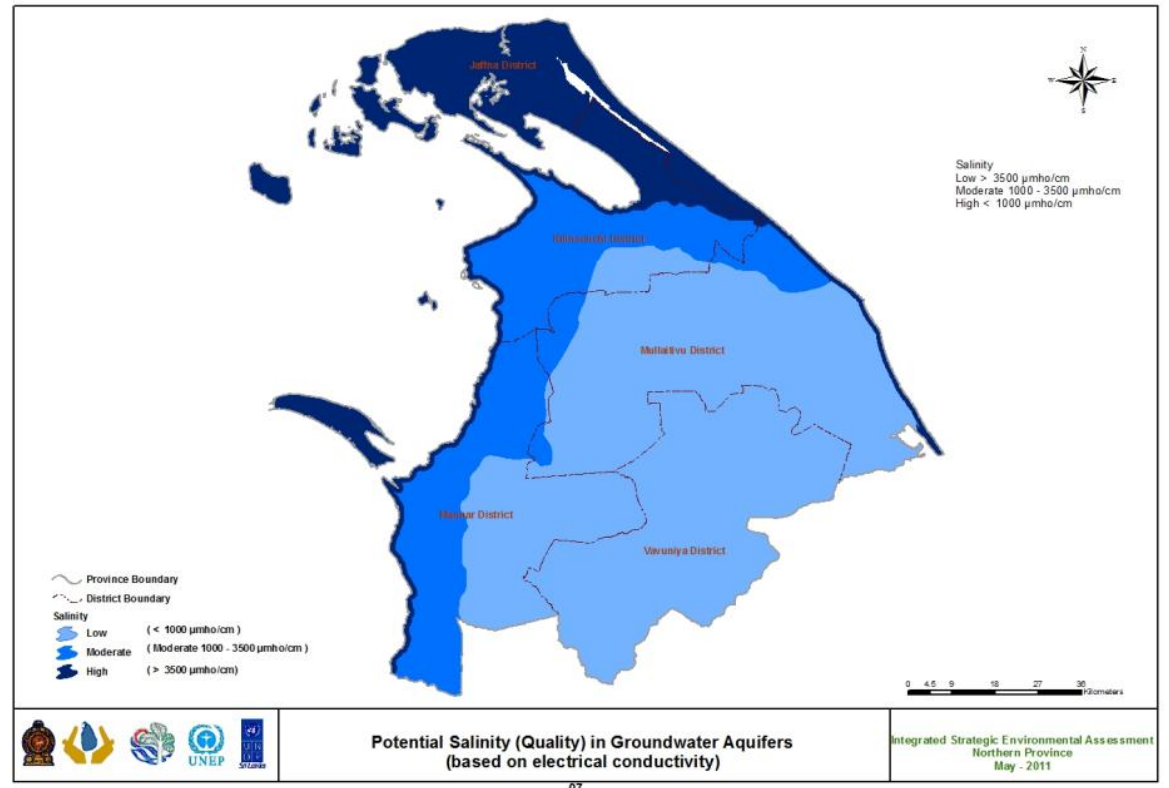

Figure 2: Potential salinity in groundwater aquifers in the Northern Province

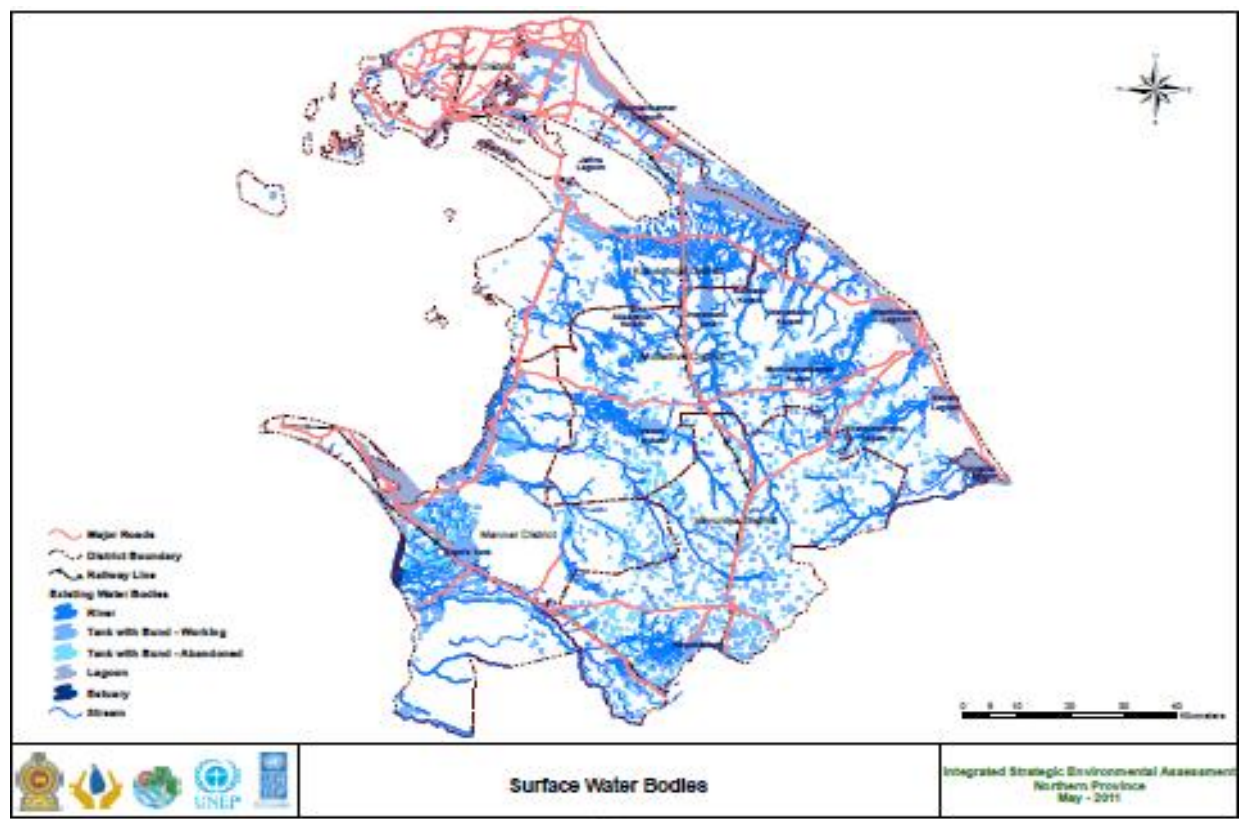

Figure 3: The presence of surface water bodies in the Northern Province 


\section{Jaffna Peninsula}

The Jaffna Peninsula, longitude $79^{\circ} 45^{\prime}-80^{0} 20^{\prime}$ E Latitude $9{ }^{0} 30^{\prime}-9^{0} 50$ ' N, with a land mass of 400 sq. miles forms the northern extremity of Sri Lanka. It has sea (Palks Straight) on its western, northern and eastern sides and the Jaffna Lagoon in the South. The Islands of Mandaitivu, Karainara, Kayts, Eluvativu, Analaitivu, Punkudutivu, Nainativu and Delft lie to the west of the Peninsula.

A long stretch of water, forming an internal lagoon almost divides the area into two, with the northern outlet at Thondaimanar and the southern at Ariyalai. These two drainage outlets are not controlled and regulated for the prevention of sea water ingress and for the conservation of fresh water with the Peninsula. While the seasonal rainfall exhibits a definite rhythmic pattern, there is however considerable variation in from year to year. This variability of rainfall has always been a major hazard in agricultural enterprise in the area. At the end of August, water tables are generally at their lowest and the salinity of water is highest. The recharge to ground water in the Peninsula is almost entirely from rainfall percolation; any significant contribution by lateral percolation from the basement is very unlikely.

With regard to the ground water there is a heavy draw off from wells which are more than 84,000 . Of these, about 66,000 are domestic wells where water is drawn for domestic purposes only and the balance 18,000 is Farm or Agricultural wells (WRB, 1968). The intensity of agricultural wells is very high in the Urumpirai, Urelu, Mallakam, Uduvil areas where there are over 30 such wells in every 100 acres. These coincide with areas of heavy draw-off. As would be expected, largest number of domestic wells is to be found in Jaffna Town and the neighboring Kokkuil areas with intensities of 152 and 129 per 100 acre respectively. These are areas of heavy draw off for domestic purposes.

The present consumption of water for domestic and agricultural uses is estimated at $49 \mathrm{mn} \mathrm{m} 3$ per annum. The recharge of rainfall in a normal year is $112.1 \mathrm{mn} \mathrm{m} 3$ with a discharge to the sea of $62 \mathrm{mn} \mathrm{m} 3$. In a lean year however when only about $62.5 \mathrm{mn}$ $\mathrm{m} 3$ of rainfall recharge was available, the discharge to the sea would have been of the order of $12.4 \mathrm{mn} \mathrm{m} 3$, but with the prevalence of the same rate of consumptive use. The recharge in a rainy season is about $220.5 \mathrm{mn} \mathrm{m} 3$. A $170 \mathrm{mn} \mathrm{m} 3$ of water is available to augment the ground storage by depressing the interface and discharge to the sea.

It would, thus, be evident that ground storage of large amounts of water capable of maintaining supplies during a continuous spell of consecutive dry years, is not possible, and drastic reductions in rates of extractions of water from wells would have to be made, to tide over such spells. During wet spells such as during a heavy rainfall season a very large proportion of the recharge will discharge to the sea (WRB, 2009). 


\section{Mannar, Kilinochchi and Mulativu Districts}

Mannar is situated in an area of calcareous sedimentary rocks which contain some significant limestone, aquifers. The sedimentary zone extends northwards and has several sub-basins, one of which is the Murunkan basin. All the sediments thicken seawards and thin out inland as they reach the hard rock's of the mainland. In the Mannar-Murunkan area the limestones, which appears to be partly karstified, are covered largely by Quaternary sands and clays, and on Mannar Island, many meters thickness of aeolian dune sands. Hydro-geology of the Mannar Island is thereby based on clear water collection, in the sand dunes.

People mostly depend on the shallow dug wells or locally made hand pump wells installed at the sand aquifers. Saline intrusion is reported especially in dry periods and some aquifers have totally been polluted with saline water by over extractions. Only available pipe scheme within the project area (25 GND's in Mannar DS division) is the Mannar integrated water supply system which integrates Vankalai, Thirukathikeshwaram and Mannar town pipe water supply schemes. The sources of ground water for the pipe water supply is from Murukkan well field downstream of the Giant Tank and Thodakadu well field in the Mannar Island which belongs to the National Water Supply and Drainage Board.

Mannar - Murukkan area is an important area of paddy cultivation since before 600 AD. Irrigation of this paddy crop, grown during the Maha growing season, utilizes surface water for irrigation, diverted from the Aruvi Aru, temporarily stored within the Giant's Tank and distributed periodically via a system of channels and small tanks. During the drought of 1972-73 several tube wells were dug to supplement surface irrigation water but After two moderately successful years these farmers experienced partial or total crop failure during the third yala season.

The cause of crop failure was thought to be the result of the accumulation of sodium salts within the soil layers due to the application of brackish to saline groundwater. This high salinity was thought to be due to the intrusions of marine saline water into the limestone aquifer caused by the high rates of abstraction. Groundwater through flow is of the order of 4.5 MCM per annum through this area. The chemical quality of the aquifer water with the limestone trough recharge area is good, poor quality water being found within stagnant zones. Groundwater quality slowly deteriorates down dip but is still good in the areas immediately south and west of the Giant's Tank.

Within the limestone aquifer groundwater quality deteriorates from 2000 umhos/cm within the Uyilankulam area to more than 5000 umhos/cm adjacent to the coast. A more marked deterioration is noted within the upper alluvium aquifer where highly saline groundwater occurs inland from the coast. The performance of the Mannar - Murunkan aquifer must be carefully monitored in future by regular 
collection of data from a regional observation network especially to determine the response of the aquifer to the widely differing climatic regimes that affect the area. A review of the data collected should determine the feasible extent of any future groundwater development programme. The data availability in Kilinochchi and Mulatiuv are very limited.

\section{Vavuniya}

The total population in Vavuniya District is 241,659 out of which there are 53,237 urban population located in the Vavuniya Division. If an average of 120 liters/person is required for daily use, then the total water demand is 1,687,646 gallons/day. However, at present the maximum extraction (from ground water) is around $700 \mathrm{cum} /$ day or 184920.4 gallons/day which is only $11 \%$ of the requirement. It is abstracted by 8 wells ( 4 shallow and of large diameter and 4 small diameter and relatively steeper).

In an effort to improve the resources, an additional drilling was done in 2003 mainly in the immediate town area and 3 deep tube wells were eventually developed and turned over to the NWSDB for the town water supply. Therefore, the town water supply now comprises 11 wells, only 8 of which can presently be operated due to the low efficiency in the pumps. The distribution system is beset with leaks and water is available only for 2-3 hours/day in the dry season and 12 hours in the monsoon. The existing wells especially those located near Vavuniya Tank are extremely vulnerable to get polluted from agrochemicals and also from the sewerage and any other liquid or soluble contaminants.

The main issue with the water quality in most of the groundwater sources is the low acceptance by the users, mainly due to high concentration of hardness and alkalinity that leads to even calcite deposits blocking the pipes. Seasonal fluctuation of Nitrite and Fluoride in some areas is also a critical factor to be considered as concentrations of those parameters exceed the safe drinking water standards due to contamination and low recharge of aquifers in the dry spells.

\section{Planned Water Supply Schemes In The Northern Province}

\section{Major Water Supply Schemes Planned By The National Water Supply And Drainage Board}

\section{DB Assisted Dry Zone Urban Water and Sanitation Project (ADB 5)}

This project has been designed to augment water supply and sanitation facilities in the districts of Vavuniya, Mannar and also Chilaw and Puttalam. The Ministry of Water Supply and Drainage is the Executing Agency for the Project and the National Water Supply and Drainage Board (NWSDB) is the implementing Agency. In Vavuniya, the main item of the project is the construction of an earth 
dam of maximum height of $10.5 \mathrm{~m}$ and length of $3 \mathrm{~km}$. It will store $3.849 \mathrm{MCM}$ at FSL. It is expected to abstract $6700 \mathrm{mcm} /$ day from the reservoir for drinking water purposes. The water will then be pumped to a water treatment plant located about $1.5 \mathrm{kim}$ distance away from the bund and after treatment will be distributed to $23 \mathrm{GN}$ divisions in Vavuniya District. In addition to this surface water supply, 4 existing tube wells will be rehabilitated and 14 new tube wells will be constructed to increase the total abstradtion rate ofr the ground water to 3000 cum/day.

In Mannar, in the Murukkan well field, the existing 4 wells will be rehabilitated while 8 new wells will be constructed. The expected ground water will be 14,800 cum/day in 2030 to cater to the demand of 11,923 cum/day for the water serving population of 37,831 . The project will also improve the water conveyance system by replacing the transmission main and water distribution system. It will also improve the existing gas chlorination systems to provide basic water disinfection. There would be new overhead reservoirs and ground sumps constructed to facilitate the storage of the water prior to distribution.

\section{Jaffna and Kilinochchi Water Supply and Sanitation Project (ADB 6)}

This is a ADB asissted proejct with a view to assist the Government of Sri Lanka in social and physical reconstruction in the north of the island subjected to almost two decades of armed internal conflict. Ministry of Water Supply and Drainage as the executing agency through the National Water Supply and Drainage Board (NWSDB), particularly its Jaffna Regional Office (JRO), is responsible for overall coordination of project execution and implementation of the water supply and sanitation component. Ministry of Local Government and Provincial Councils (MLGPC) through the Northern Provincial Council-Provincial Irrigation Department (NPC-PID) is responsible for overall coordination of project execution and implementation of the Iranamadu Tank component. This Project is now in the initial phases of design.

The Project will comprise three components: (i) rehabilitating, expanding, and developing water and sanitation infrastructure; (ii) strengthening water resource management; and (iii) enhancing implementation and management capacity of key institutions and providing support for project management and implementation activities. The water supply works will comprise: (i) rehabilitation and improvement of headworks at the Iranamadu Tank to increase efficiency levels and water resources; (ii) water intake at Iranamadu Tank, raw water supply system, water treatment plant, and treated water pumping station; (iii) treated water transmission mains to the Jaffna Municipality, and (iv) connections to urban council and pradeshiya sabhas en-route3 involving 12 off-takes. 
From the treated water transmission main, the Project will provide (i) new distribution systems for Jaffna Municipality and Chavakachcheri Urban Council, including access to household connections and metered community facilities in poor areas; (ii) new distribution systems for selected pradeshiya sabhas of the Jaffna and Kilinochchi districts including extensions to property boundaries for ease in connecting household and community connections; (iii) installation of bulk/system water meters; (iv) a leak detection program for rehabilitation and strengthening of the existing distribution network; and (v) spare parts and maintenance equipment. Provision of a sanitation system comprises: (i) sewage collection system, (ii) sewage treatment plant, (iii) treated effluent sea outfall, and (iv) maintenance equipment.

On the completion of the project over 60,000 connections will be provided in the Jaffna and Kilinochchi districts and 300,000 people will benefit. Over 20,000 connections people in the Jaffna Municipal Council area and 80,000 people in the area will benefit from the project.

\section{Other Projects}

In addition to these large projects, there are medium and small scale projects opeartive in the Northern Province. There are 9 medium scale projects on ground water extraction in operation in Adampan, Vedithalathivu, Mallawi, Odusudan, Nedunkerni, Velvatithurai and Point Pedru etc. There is a pipeline constructed to Kilinochchi from Jaica funds. In order to cater to the large influx of pilgrims to Madhu Church, a small water supply scheme has been initiated. In addition to these there are about 30 small projects with about 6-7 connections scattered in Jaffna Peninsula. In addition to the urban water schemes there are rural water schemes in operation and these are funded by both Australian Government and World Bank. The coverage of pipe-borne water supply in Jaffna is about 3.2 percent of the population and less than 0.5 percent households have access to pipe - borne water.

\section{Water Resources Development By Mahaweli Authority of Sri Lanka (MASL)}

\section{North Central Province Canal (NCP Canal) Project}

A canal has been proposed from the Moragahakanda Reservoir to Mankulam in the Northern Province. The total length of this canal is $66 \mathrm{~km}$ and will be traversing on a ridge. It is expected that the water thus brought from the Central Province will augment the tanks lying on valleys throughout its route as shown in Figure 4 below.

NCP Canal traverse through some forest and wildlife reserves as it traverses from the Central Province to the Northern Province. When it enters Northern Province it comes through Mudunkulam Proposed Nature Reserve and then traverses through forest reserves up to Kilinochchi. 


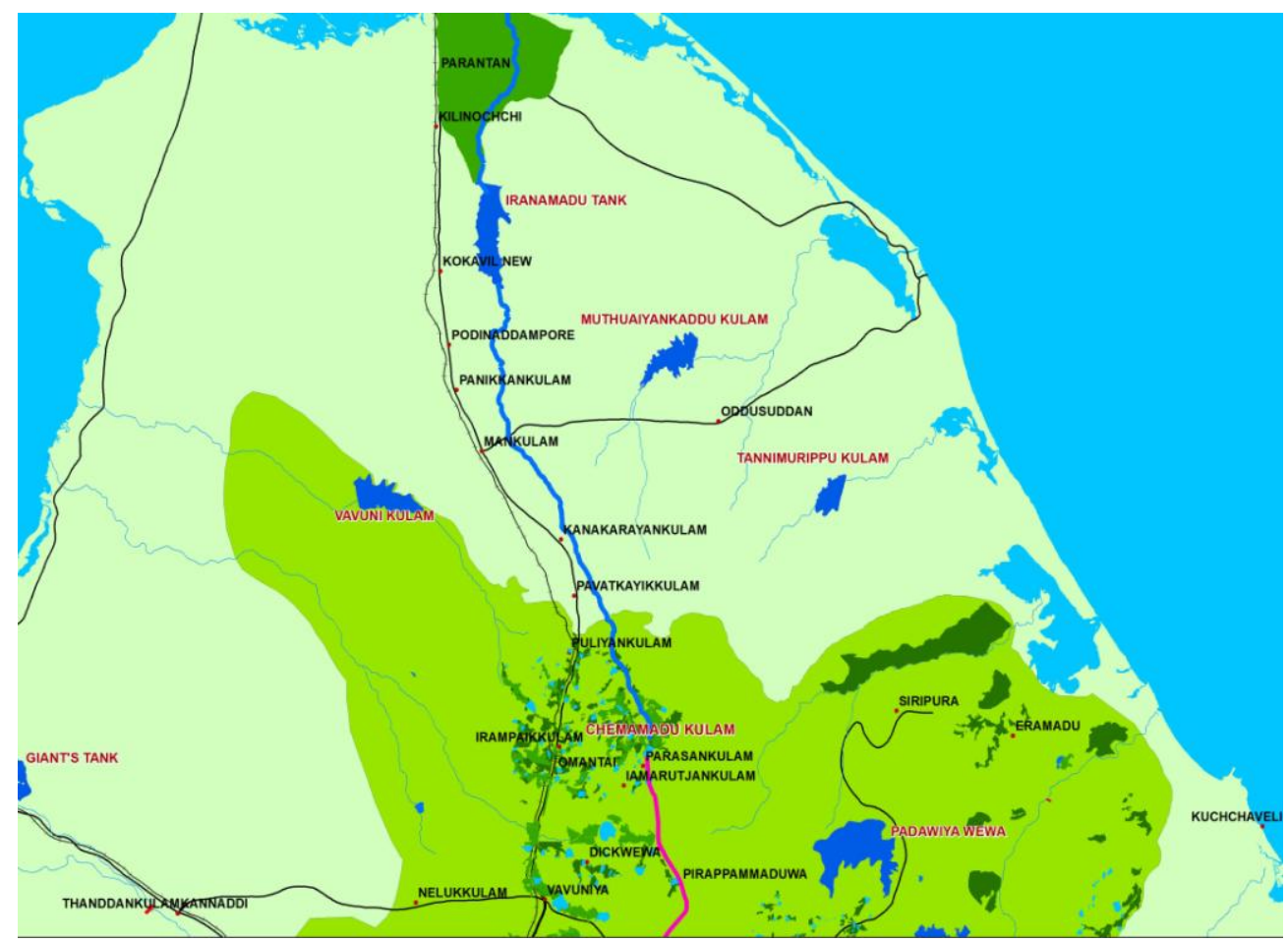

Figure 4: NCP Canal from Moragahakanda Reservoir to Kilinochchi

\section{River to Jaffna}

The proposal envisages conserving in the Elephant Pass lagoon, flood runoff from Iranamadu reservoir which spills into the Kanagarayan aru, from time to time. This lagoon had been isolated from the sea by salt water exclusion structures at its eastern and western ends, (which however are now in a state of disrepair). Over the years, by a process of infinite dilution, the lagoon would be converted to a fresh water lake. At a later stage it would be connected to the Vadamarachchi lagoon, which too would eventually become a fresh water lake, and the ground water table in the Jaffna peninsula would be considerably enhanced. The lagoons in connection with the Project are shown in Figure 5 below;

\section{Water Issues On The Face of Accelerated Development}

There will be increasingly intense competition between industry, tourism, housing and farming for the increasingly scarce supplies of clean water on the Jaffna Peninsula. Without a careful and urgent large-scale water supply and water 
treatment schemes, the re-development of this area will not be environmentally, economically or socially sustainable. This is the biggest priority for the Province.
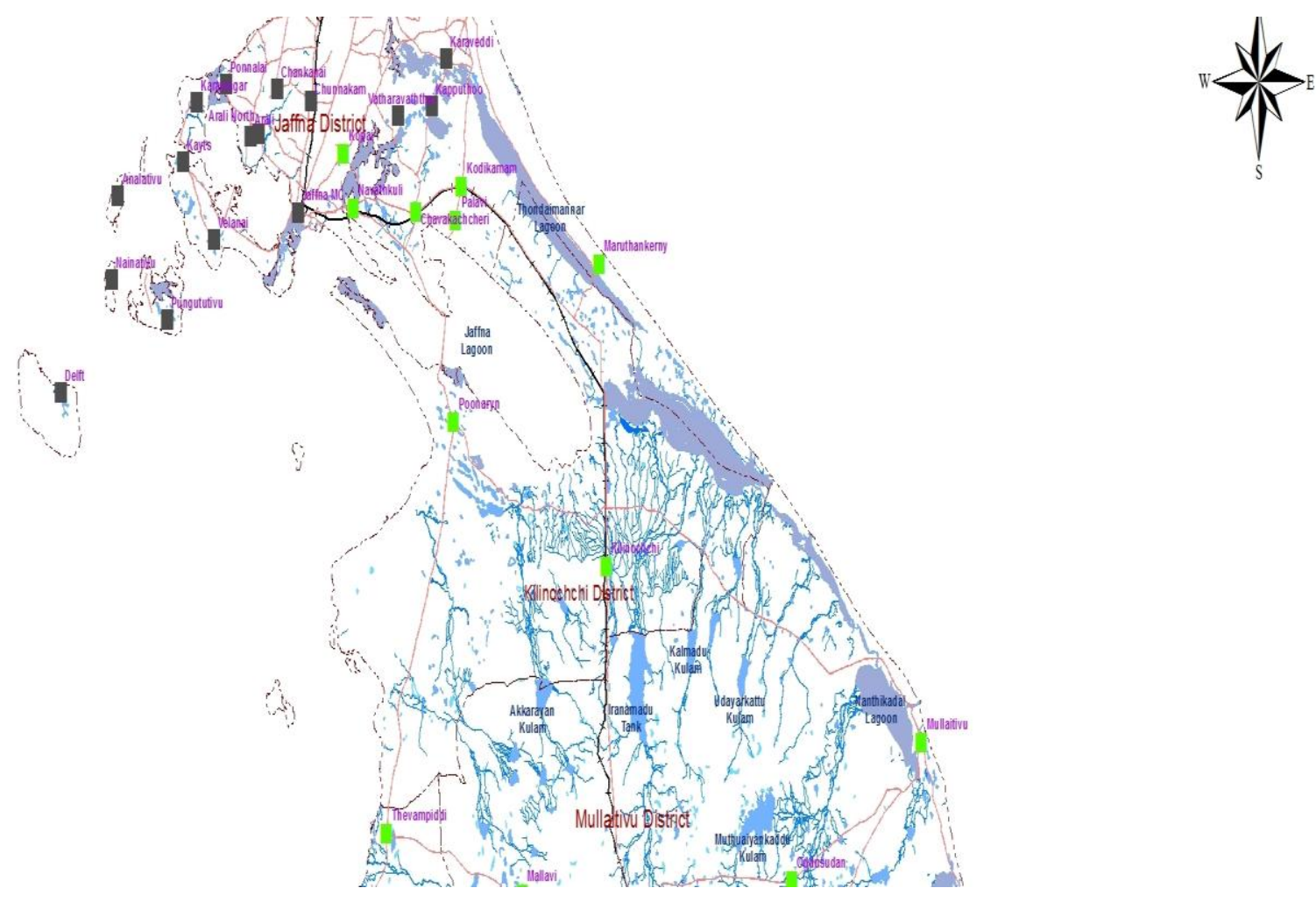

\section{Figure 5: River to Jaffna Project}

The present and future potential for agricultural crop production in the Northern Province is very high. Agrochemicals are being extensively used for cultivation. However, due to the reduced availability of water reduced flushing and accumulation of these agrochemicals may pose a serious health issue in especially Jaffna Peninsula since the main source of water is the aquifer, which is fragile and at risk from over extraction and contamination from leachates.

Tourism, holiday homes, quarries, industry, harbors and infrastructure projects are all required to rejuvenate the economy of the Northern Province - but these types of development must be planned and implemented with care. Sri Lanka has an excellent knowledge of how to plan and care for coastal areas and this knowledge must be used to constructively direct development so that these important 
environmental assets will continue to be able to generate sustainable growth and income

The main issue with the water quality in most of the groundwater sources is the low acceptance by the users, mainly due to high concentration of hardness and alkalinity that leads to even calcite deposits blocking the pipes. Seasonal fluctuation of Nitrite and Fluoride in some areas is also a critical factor to be considered as concentrations of those parameters exceed the safe drinking water standards due to contamination and low recharge of aquifers in the dry spells.

\section{Towards Sustainable Development In The Northern Province}

A landmark effort taken in ensuring sustainable development in the Northern Province is the Integrated Strategic Environmental Assessment (ISEA) which was carried out by the Central Environment Authority (CEA) of the Ministry of Environment formed a partnership with the Disaster Management Centre (DMC) of the Ministry of Disaster Management. This involved an undertaking by more than 25 agencies working together to understand the natural resource base after the conflict and to provide strategic information support to facilitate the intended accelerated development in the Province. The publication is accompanied by the Map Compendium that was developed by the Urban Development Authority.

The key output of the effort was an opportunity map which incorporated all the natural resource capital in the Province and the potential for development. Then areas were demarcated for development so that when opportunities for development arise they can be easily relegated to these areas. However, this initial effort has to be further fine tuned and then made mandatory so that all the Divisional Secretariats will adopt it in making decisions. following are some of the recommendations that can be adopted to make water use sustainable in line with the proposed development.

\section{Improve the Regulatory Process}

Watersheds in the Northern Province need to be conserved well to enable sufficient quantity of water with good quality to downstream uses. In this regard, the ISEA done for the North should be promoted among the policy makers and planners so that the recommendations will be taken up for decision making. Awareness workshops need to be done at first district level and then divisional level to institutionalize the recommendations of the ISEA. Central Environmental Authority should take the lead in making the ISEA mandatory to all Provinces. Water Resources Board needs to ensure that ground water extraction will not lead to ground water depletion. In the districts where ground water is the predominant source of water, there are profuse extraction i.e. Jaffna Peninsula, Mannar and this 
leads to salinity intrusion too. Water Resource Board needs to have district and divisional level representation to ensure this as they have the mandate for it.

\section{Change The Approach To Water And Improve Institutional Collaboration}

Water should be managed on a river basin approach. This will enable to conserve both the quality and quantity of water. All the players will integrate towards designing a proper approach and the implementation of the same can be at the District level and Divisional level supervised and overseen by the River Basin Authority. Integrated water management needs to be practiced so that water and watersheds can be conserved effectively while attaining sustainable development

\section{Improve the Technical Competence/Use Alternatives}

It is required to find more ground water sources using remote sensing and geological prospecting and map this division wise. The water availability, demand and supply in the different districts in the Northern Province need to be updated for present and future scenarios. Rather than resorting to pumping from far away sources which needs lot of energy, sources need to be found from close by - for example tanks needs to be rehabilitates to supply the water to the neighborhood communities.

Promoting rain water harvesting both as tanks and as pathahas - this can be built in to the building codes. The scattered tanks in the Northern Province should be rehabilitated so that water is made available for irrigation, cultivation and other purposes close at hand. Their catchments need to be protected to ensure a continuous supply of water with good quality.

\section{Conserve Water/Demand Side Management}

It is best to separate the water for drinking from water from other purposes, for example toilet use etc and the devises can be manufactured to suit this purposes. These should be marketed well so that people will use them commonly. Suitable steps should be taken by the respective authorities to conserve water - both quality and quantity. For example, CEA should make sure that the water bodies are not polluted by industries and others while Forest Department and Department of Wildlife Conservation should ensure the protection/conservation of their habitats. Irrigation Department and Department

\section{References}

ADB Technical Assistance Consultant's Report (2008) Sri Lanka: Small Towns and Rural Arid Areas Water Supply and Sanitation Project no. 3738101, Nippon Koei Co. Ltd in association with IDP Consult Inc. - Main Report 
ADB Report on Democratic Socialist Republic of Sri Lanka: Jaffna and Kilinochchi Water Supply and Sanitation Project, Project Number 37378, September, 2010

Feasibility Study on the North Central Province Canal Project Inception Report on the ADB Assisted Dry Zone Water and Sanitation Project - Sri Lanka, ADB Grant No. 0129 (SF), November 2010.

Mahaweli Master Plan, MASL.

Mendis, D.L.O. Water Resources Development with special reference to Moragahakanda Reservoir and NCP Canal and River for Jaffna

Northern Provincial Council (2011), Budget Speech of the Hony Governor.

Proceedings of the Interactive Workshop on using ISEA as a tool for IWRM, Vavuniya Kachcheri, 16 ${ }^{\text {th }}$ February, 2012.

Resource Profile (2011), Divisional Secretariat, Vavuniya.

Resource Profile (2011), Divisional Secretariat, Vavuniya South.

Short investigation report on water supply to the urban area of Vavuniya by the ADB Assisted Dry Zone Urban Water and Sanitation Project Package C, RDC in association with NIRAS, January 2011.

Statistical Abstract of Vavuniya District (2011), District Secretariat, Vavuniya UNDP \& CEA (2010) Integrated Strategic Environmental Assessment for the Northern Province.

Water Resources Board (2009) Water Resources in Northern Province. 